\title{
Land Use Change and the European Biofuels Policy: The expansion of oilseed feedstocks on lands with high carbon stocks ${ }^{\text {it }}$, 败访
}

\author{
Alexandre Strapasson ${ }^{1}$, Juliana Falcão ${ }^{2}$, Timo Rossberg ${ }^{3}$, Grahame Buss ${ }^{4, *}$, Jeremy Woods ${ }^{1}$ and \\ Steven Peterson ${ }^{5}$ \\ ${ }^{1}$ Imperial College London, London, UK \\ 2 Independent Consultant, Brasilia, Brazil \\ 3 Independent Consultant, London, UK \\ ${ }^{4}$ LCAworks Ltd, Bedford, UK \\ ${ }^{5}$ Dartmouth College, Hanover, United States
}

Received 20 December 2018 - Accepted 12 August 2019

\begin{abstract}
The focus of this article is on the potential land use change impacts associated with the oilseed-based biodiesel consumption. The three main crops used for biodiesel production to date are oilseed rape (OSR), soybeans and oil palm. Therefore, the objective of this paper is to provide a technical assessment of potential land use change arising from the growth of these three major crops at global level, obtained through a broad country-level analysis for their respective major producing countries. The article presents an historical data analysis, evaluating the interaction between the expansion and contraction of these three crops over the last three decades (with a closer look from 2008) together with the carbon stock changes to the land. We categorise the land use by its carbon stock and resulting carbon stock changes from land use change. Crops aimed at the production of ethanol, such as maize (corn), sugarcane, wheat, cassava and sugar beet, although extremely relevant for biofuel policies, are not the subject of this present study. While we did not know at the time of writing this report how the term "significant" would be defined in the EU delegated act we concluded from the analysis of the historical data and using the high ILUC-risk definition as it stands, that the emissions associated with palm and soy are significant. For oil palm, we take Indonesia and Malaysia as proxy for the global position. We calculate an average expansion of $29 \%$ on high carbon stock land. For soy, we calculate a global average of $19 \%$ expansion. We calculate the global average greenhouse gas emissions intensities based on the ILUC-risks as $56 \mathrm{gCO}_{2} \mathrm{eq} / \mathrm{MJ}$ for soy oil and $108 \mathrm{gCO}_{2} \mathrm{eq} / \mathrm{MJ}$ for palm oil. Future projections (OECD-FAO, 2017) suggest these numbers could drop significantly. We do not find evidence for high ILUC-risk expansion of oilseed rape.
\end{abstract}

Keywords: biodiesel / land use change / ILUC / palm / soy / rapeseed

Résumé - Changement d'affectation des sols et politique européenne sur les biocarburants : l'expansion des matières premières oléagineuses sur les terres à fortes réserves de carbone. Cet article se penche sur les impacts potentiels du changement d'affectation des sols associés à la production de biodiesel à base d'oléagineux. Les trois principales cultures utilisées à ce jour pour la production de

\footnotetext{
Contribution to the Topical Issue "Biodiesel / Biodiesel".

is is A supplementary document on "Land Use Change and the European Biofuels Policy" is available in public domain on the LCAworks official website at: www.lcaworks.com. It is a full research report prepared by the authors, including further literature review and references, methodological clarifications and complementary discussions about the risks associated with a potential expansion of energy crops in high carbon stock lands for the production of biodiesel.

*Correspondence: grahame. buss@lcaworks. com
} 
biodiesel sont le colza oléagineux, le soja et le palmier à huile. Par conséquent, l'objectif ici est de fournir une évaluation technique du changement d'utilisation des sols potentiel pour ces trois principales cultures au niveau mondial, obtenue par une analyse globale au niveau national pour leurs principaux pays producteurs respectifs. L'article présente une analyse des données historiques, évaluant l'interaction entre l'expansion et la contraction de ces trois cultures au cours des trois dernières décennies (avec un regard plus précis à compter de 2008), ainsi que l'évolution du stock de carbone de la terre. L'intention est de catégoriser ces utilisations des terres en fonction des stocks de carbone et de leurs variations. Les cultures destinées à la production d'éthanol, telles que le maïs, la canne à sucre, le blé, le manioc et la betterave à sucre, bien qu'extrêmement pertinentes pour les politiques en matière de biocarburants, n'ont pas été prises en compte dans la présente étude. Étant donné que nous ne savions pas encore, au moment de la rédaction de cet article, comment le terme «significatif» serait défini dans l'acte délégué de la Commission européenne, nous avons conclu à partir de l'analyse des données historiques et de la définition actuelle d'un risque élevé de changement indirect d'affectation des sols (ILUC), que les émissions associées au palme et au soja sont importantes. Pour l'huile de palme, nous prenons l'Indonésie et la Malaisie comme représentants de la position mondiale. Nos calculs mettent en évidence une expansion moyenne de $29 \%$ sur des terres à stocks de carbone élevés. Pour le soja, les calculs aboutissent à une expansion mondiale moyenne de $19 \%$. Les intensités moyennes globales des émissions de gaz à effet de serre sur la base des risques ILUC seraient de $56 \mathrm{gCO}_{2} \mathrm{eq} / \mathrm{MJ}$ pour l'huile de soja et de $108 \mathrm{gCO}_{2} \mathrm{eq} / \mathrm{MJ}$ pour l'huile de palme. Les projections futures (OCDE-FAO, 2017) suggèrent que ces chiffres pourraient chuter de manière significative. Nous ne trouvons aucune preuve d'expansion à haut risque dans le cas du colza oléagineux.

Mots clés : biodiesel / changement d'utilisation des terres / ILUC / palme / soja / colza

\section{Introduction}

This study provides an assessment of land use changes for the major biodiesel crops, soybean, oil palm and oilseed rape OSR), from 1990 to the present. The context of the study is the compromise reached in June 2018 between the European Parliament and the EU Council. The compromise reopens the Indirect Land Use Change (ILUC) issue with a focus on the ILUC risk of feedstocks whose expansion is observed on high carbon stock land. The compromise text from Council and Parliament provides for a freeze on all high ILUC risk feedstocks at the level reached in 2019 from 2021 until 2023 and with a complete cessation by 2030 . Crop based biofuels overall will be permitted by Member States at 2020 levels up to a cap of $7 \%$. At the time of writing this article, the Commission was still expected to provide a delegated act, defining the High ILUC-risk feedstocks. They might also provide a methodology for the certification of low ILUC-risk production which could be exempted from the cap. Since this time, the Commission has finally adopted its delegated act on March 13, 2019. This article does not address the question of the certification of low ILUC-risk production.

\section{Method}

We start from the definition of high indirect land-use change-risk food or feed crop-based biofuels as "bio-liquids and biomass fuels produced from food or feed crops for which a significant expansion of the production area into land with high carbon stock is observed". In addition, the Renewable Energy Directive(RED) requires that biofuels shall not be made from raw materials obtained from land with high carbon stocks such as forests and wetlands if the land had that status in January 2008.
The report assesses the land use expansion of soybean, oil palm and oil seed rape at regional, country and global levels. The assessment is prepared based on: (1) a literature review of land use change (e.g. dynamics of cropland, pasturelands, forestlands and wetlands), emissions associated with Agriculture, Forest and Other Land Use (AFOLU), oil crop productivity, and the production of vegetable oils; and (2) estimates using historical data (e.g. oil production, land area and crop yields) from FAO, USDA and EUROSAT databases. Countries which presented a net reduction in natural vegetation (e.g. forestlands, wetlands and natural grasslands), where subject to further investigation in order to identify the impacts of their respective oil crops on areas with high carbon stocks. Average values for the expansion in different biomes were taken from the literature and the IPCC (2000) data.

From the published data, we:

- calculate the land use changes, $A_{0}$, per year for soybean, oil palm and oilseed rape by country and in sub-national regions where the data permit;

- calculate what part of this land use change occurs on high carbon stock lands (HCSL), $A_{1}$. The risk ratio $A_{1} / A_{0}$ is then the measure we adopt;

- calculate the average $\mathrm{CO}_{2}$ emissions from vegetation and soil per ha, $E_{m}$, from the conversion of $A_{1}$ to cropland. These carbon emission values were estimated based on IPCC (2000);

- finally, calculate the $\mathrm{CO}_{2}$ emission intensity, $E_{i}$, in $\mathrm{g} / \mathrm{MJ}$, using equation (1), by country and then globally, where $Y_{\text {oil }}$ is the established oil yield on new land per year in $t \mathrm{crop} / \mathrm{ha}$ and $E_{\text {oil }}$ is the energy content of the oil. We allocate the emission by value $\left(V_{a}\right)$ and amortise over 20 years as is standard practice. We arrive at the equation (1):

$$
E_{i}=\frac{A_{1}}{A_{0}} \cdot \frac{E_{m}}{Y_{\mathrm{oil}} E_{\mathrm{oil}}} \cdot \frac{V_{a}}{20} .
$$


Table 1. Values used in calculating the $\mathrm{CO}_{2}$ emissions per MJ (Eq. (1)).

\begin{tabular}{lll}
\hline Oil crop & $\begin{array}{l}\text { Value allocation } \\
\text { ratio }\left(V_{a}\right)\end{array}$ & $\begin{array}{l}\text { Energy content } \\
\left(E_{\text {oil }}\right), \mathrm{GJ} / \mathrm{t}\end{array}$ \\
\hline Soybean & 0.36 & 39.4 \\
Oil palm & 0.98 & 39.4 \\
Oilseed rape & 0.58 & 39.4 \\
\hline
\end{tabular}

Equation (1) calculates the carbon footprint for the production of vegetable oil associated with the expansion of oil crops over HCSL covered by natural vegetation per year attributed to the total land use expansion of that crop per year. Hence, the use of the term risk ratio. Table 1 shows value allocation ratios and the energy contents $\left(E_{\mathrm{oil}}\right)$ used in the calculation, taken from the INRAD-CIRAD-AFZ (2019) feed tables. Value allocation ratios (economic) are taken from Edwards et al. (2014), in order to account for the relative value of co-products compared to the oil from each supply chain. Yields $\left(Y_{\mathrm{oil}}\right)$ the land areas by country $\left(A_{0}\right)$, and the high carbon stock land use emissions $\left(E_{m}\right)$ are given in Tables 2 and 3.

This work follows on from previous studies by Overmars et al. (2015) and Edwards et al. (2014). Our method is consistent with these studies and LCA practice. While also using historical data to assess the share of expansion in crop area associated with the conversion of HCSL, this report differs from Overmars et al. (2015) in its approach to calculating land use change and emissions. Rather than utilising models of global cropland expansion (IMAGE and CSAM), this report bases the assessment on literature review of expansion at the national (and in some cases subnational) level. Overmars et al. (2015) also assume a counterfactual for crops grown on abandoned land on the grounds that the land would otherwise have reverted to a more natural landscape. We take the position that the land remains as cropland. Edwards et al. (2014) also assess the historical deforestation associated with biofuel crop expansion by allocating deforestation to crop expansion rather than estimating deforestation based on production trends. This allocation may not sufficiently account for the indirect link between crop expansion and deforestation (a delay between logging activities and crop establishment) that is frequently observed (Wicke et al., 2011). This paper attempts to address this complex issue through the literature review, which includes several satellite-based analyses of land use change. The countries assessed here are Argentina, Brazil, Canada, China, Czech Republic, France, Germany, Indonesia, Malaysia, Poland, Romania, the United Kingdom and the United States, as well as the European Union (EU28) as a whole.

\section{Discussion}

Table 2 shows our calculated values of the expansion ratios on HCSL and energy intensities at the national levels, and from these we determine the global values. We see a range for palm from $20-30 \%$ for the two main producer countries. For soy the range is from 0 to $28 \%$. At the level of regions within countries, these variations are larger still and where possible, these more localised values are used to determine the national averages. The amortised emission intensities for additional production are consistent with recent studies (for example, Edwards et al., 2014; Valin et al., 2015) although our values are lower. We note that our methodology does not support a position that oilseed rape nationally or globally expands directly over high carbon stock lands.

OECD-FAO (2017) projections suggest that yield increases will outstrip the requirement for land use change to meet increased demand. Whilst we acknowledge the potential for future yield increases, our work is based on historical data rather than projections and so we have not considered the potential impacts of future yields in our calculations of the expansion ratios on HCSL. Table 3 summarises of our estimates of the GHG emissions for soy and palm expansion over native vegetation HCSL based on data covering 2006-2016.

Any calculation of this sort contains considerable uncertainties, particularly in the calculation of the expansion ratio, but also the specific prior land use. Where there is a significant range in the HCSL use change, we have used the data covering the most recent period and where available the value at the lower end to reflect the increasing efforts to reduce the conversion of HCSL seen more recently. We have not considered counterfactual land use changes. This might include using otherwise abandoned cropland, where the counterfactual would be a return to a more natural landscape. This would not be consistent with an analysis based on the historical record.

In the following sections we provide further details of the analysis of the three crops. Considerably more detail is contained in the body of the supplementary document on the background to the oil markets, carbon stocks, the land use change assessments and estimates of future production.

\subsection{Soybean}

We consider the four nations that supply $85 \%$ of world production: Argentina, Brazil, China, and the USA. Table 4 summaries the expansion onto high carbon stock lands in these regions.

\subsubsection{Argentina}

Recent land use changes in Argentina have occurred over forestlands as well as Chaco, with an almost linear decrease in the past decades. Pastureland and cropland have both expanded near linearly, directly or indirectly affecting these land use changes observed in forestlands and possibly in the "other land" category (see Appendix A). Argentina established a new forest code (Ley de Bosque Nativo) in 2007. Since then, the country was expected to reduce its deforestation rates, but the problem continued. From 2007 to 2014,5 Mha of native vegetation were lost, with $90 \%$ of the deforestation occurring in the North Region, including the Gran Chaco area (Larraquy, 2016). The country produces soybean in different states, from North Region (e.g. States of Salta, Chaco and Formosa) to Centre Region (e.g. States of Cordoba, Santa Fe, Buenos Aires and La Pampa). Among other initiatives to reduce deforestation related to the cultivation of soybean, the Round Table on Responsible Soy - TRS (2018) sets standards for its sustainable production but has had limited success to date (Goni, 2018). 


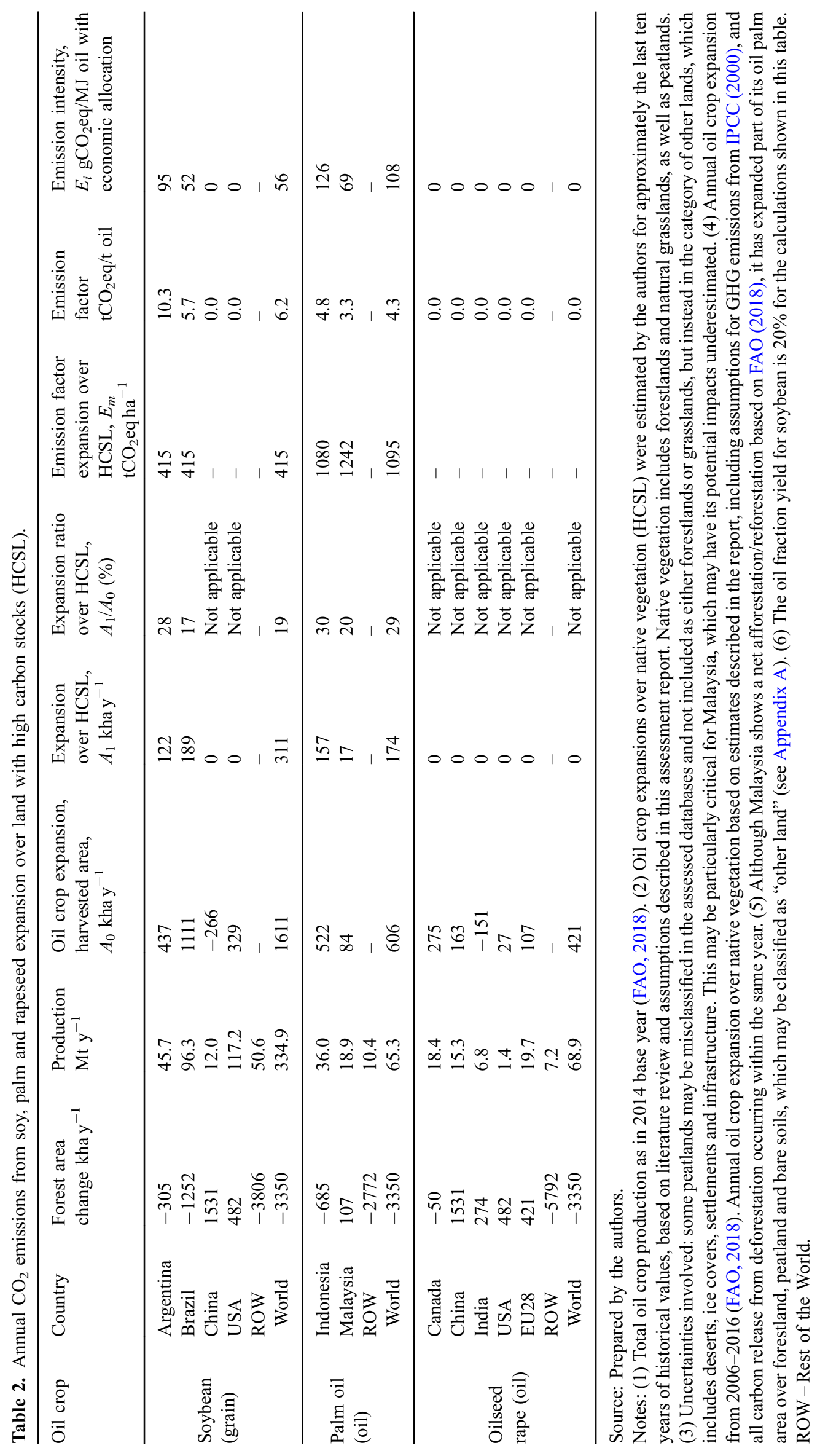


A. Strapasson et al.: OCL 2019, 26, 39

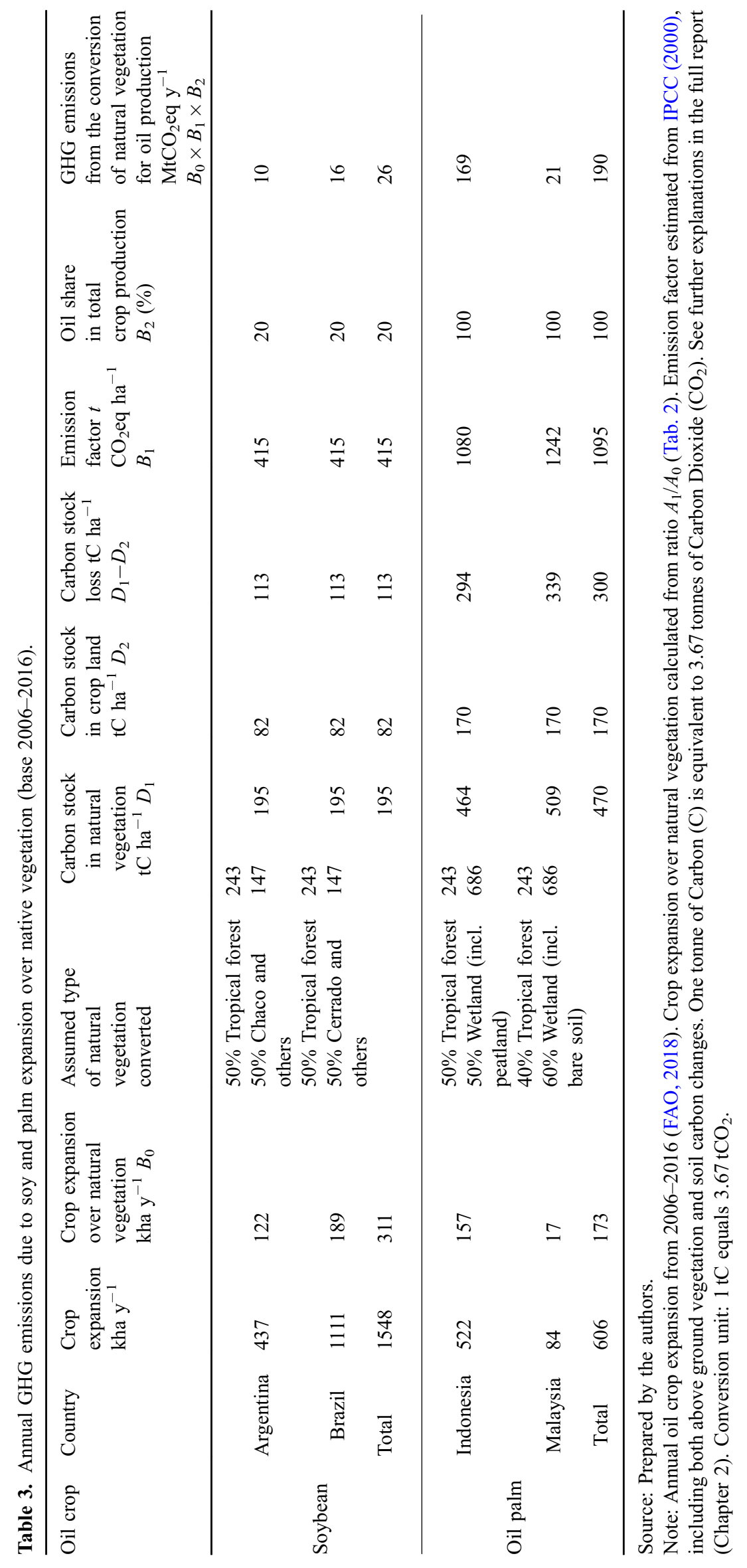

Page 5 of 12 
Table 4. The expansion of high carbon stock lands for soy production.

\begin{tabular}{|c|c|c|c|c|c|}
\hline Country & Sub-region & Forestland dynamics & $\begin{array}{l}\text { Total soy } \\
\text { production } \\
\text { in grain (2016 } \\
\text { base-year) Mt }\end{array}$ & $\begin{array}{l}\text { Share of global } \\
\text { production }(\%)\end{array}$ & $\begin{array}{l}\text { Approximate share } \\
\text { of recent soy expansion over } \\
\text { natural vegetation }(\%)\end{array}$ \\
\hline \multirow[t]{2}{*}{ Argentina } & & Net deforestation & 58.8 & 17 & 28 \\
\hline & MATOPIBA & Net deforestation & 11.6 & 4 & 62 \\
\hline Brazil & All other regions & Net deforestation & 84.7 & 25 & 11 \\
\hline China & & $\begin{array}{l}\text { Net afforestation/ } \\
\text { reforestation }\end{array}$ & 12.0 & 4 & Not applicable \\
\hline United States & & $\begin{array}{l}\text { Net afforestation/ } \\
\text { reforestation }\end{array}$ & 117.2 & 35 & Not applicable \\
\hline Other nations & & - & 50.6 & 15 & - \\
\hline World & & Net deforestation & 334.9 & 100 & 19 \\
\hline
\end{tabular}

Source: Prepared by the authors.

Note: Total soy production based on FAO (2018). Approximate share of recent (about past 10 years) soy expansion over native vegetation were estimated by the authors, based on literature review. World share assumes a weighted average of the situation occurred in the listed countries, excluding other nations. MATOPIBA region is comprised of the Brazilian State of Tocantins (TO) and parts of the States of Maranhão (MA), Piauí (PI) and Bahia (BA).

The Argentinian environmental legislation aims at reducing the deforestation rates observed in many biomes across the country, but there is a risk of non-compliance (NEPCon, 2017). There is a high deforestation rate including from soy expansion, which has partially expanded over critical wetlands (Herrera et al., 2013). Argentina increased its soy production by 10.9 Mha from 8.6 Mha in 2010 to 19.5 Mha in 2016, according to data from FAO (2018). In the same period, total cropland increased by $11.6 \mathrm{Mha}$ from $28.6 \mathrm{Mha}$ (2010) to 40.2 Mha (2016), whilst total pastureland increased by $8.6 \mathrm{Mha}$ from 99.9 Mha (2010) to 108.5 Mha (2016). Cropland was $57 \%$ of the total agricultural land, and pastureland $43 \%$, in 2016. At the same time, $5 \mathrm{Mha}$ of deforestation occurred reducing the forest area from $31.7 \mathrm{Mha}$ (2010) to $26.8 \mathrm{Mha}$ (2016). Based on these data and keeping the area share in the same proportion as in 2016, as well as the share of soybean in total cropland, we to estimate that approximately $28 \%$ of the total expansion of soybean may have occurred over forestlands and Chaco. In support of this, FAO data (2018) from 2007 to 2016 shows Argentina's soybean area expanded approximately $352 \mathrm{kha} /$ year, out of which $99 \mathrm{kha} /$ year occurred over natural vegetation and in line with our $28 \%$ estimate.

\subsubsection{Brazil}

Soy production occupies on $38 \%$ of Brazilian cropland. Most of the soybean production in Brazil occurs in consolidated agricultural lands, but areas of significant expansion have affected the Amazon and Cerrado. Most of its recent expansion occurred in the State of Mato Grosso (MT) and this includes areas in the so-called "Amazon deforestation arc". Amazon deforestation is complex (Strapasson, 2014). Barona et al. (2010) assessed the role of pasture and soybean in Amazon deforestation from 2000 to 2006 . They concluded that "The proximate cause of deforestation in the Legal Amazon was predominantly the expansion of pasture, and not of soybeans. However, in Mato Grosso, an increase in soybeans occurred in regions previously used for pasture, which may have displaced pastures further north into the forested areas, causing indirect deforestation".

The deforestation of Cerrado is a major issue. The expansion of soy in the MATOPIBA region was approximately $62 \%$ over forestlands (mainly Cerrado). In all the other states it occurred at about 11\% (including Amazon, Cerrado and Atlantic Forest). MATOPIBA accounted for approximately $12 \%$ of total soy production in Brazil (2016/2017 crop season), whereas all the other states combined provided $88 \%$. Based on a weighted average of the soybean production in these regions, we estimate that around $17 \%$ of the Brazilian soy area has expanded over forestlands in recent years.

From 2007 to 2016, Brazil's soybean area expanded approximately $1259 \mathrm{khay}^{-1}$ (FAO, 2018), out of which $214 \mathrm{khay}^{-1}$ occurred over natural vegetation in correspondence with our $17 \%$ estimate. Soybean area has approximately the carbon stock for average cropland. The expansion occurred over areas with an average carbon stock similar to tropical forestland. The soy expansion over native vegetation has emitted about $88 \mathrm{MtCO}_{2} \mathrm{eqy}^{-1}$, including changes in soil carbon.

\subsubsection{China}

Forestlands have been linearly increasing in China in the past decades, mainly driven by planted forests. Pastureland has been almost stable, as have soybean and oilseed rape areas. China is a major importer of soybean. Total cropland has oscillated along a downward trend in the past decades. Soybean production in China has varied substantially in the past decades. Using OECD-FAO (2017) forecast of increasing linear crop yields we may nevertheless see an increase in land for soy. The current dynamics do not correlate with the movement of soy onto HCSL. 
Table 5. Expansion over high carbon stock lands in Indonesia.

\begin{tabular}{llll}
\hline Timeframe & $\begin{array}{l}\text { Proportion of oil palm } \\
\text { area expansion associated } \\
\text { with deforestation (\%) }\end{array}$ & $\begin{array}{l}\text { Absolute expansion } \\
\text { in oil palm area associated } \\
\text { with deforestation (ha) }\end{array}$ & Study \\
\hline $1990-2005$ & $56-100$ & 1704000 to 3017000 & Koh and Wilcove (2008) \\
$1990-2010$ & 63 & Not available & Geographical magazine (2018) \\
$1990-2010$ & 33.5 & 2143000 & Gunarso et al. (2013) \\
$1990-2013$ & 51.5 & Not available & Vijay et al. (2016) \\
$1995-2000$ & 53.9 & 788000 & Austin et al. (2017) \\
$2000-2005$ & Not available & 357000 & Austin et al. (2017) \\
$2005-2010$ & Not available & 616000 & Austin et al. (2017) \\
$2010-2015$ & 18 & 585000 & Austin et al. (2017) \\
\hline
\end{tabular}

Source: Prepared by the authors, using references cited within the table.

\subsubsection{USA}

Forestlands have increased slightly and croplands decreased over the last few decades. Soybean area has been substantially increasing while total cropland has decreased. The OECD-FAO (2017) project a near linear expansion of soybean production in the US as the potential for yield increases is good. The total required land may not be significantly affected in the coming decade. In terms of emissions, forestlands are a substantial carbon sink. As with China we cannot correlate the change in soy production with expansion on high carbon stock lands.

\subsection{Oil palm}

Malaysia and Indonesia produce $84 \%$ of global palm oil. In this work these two nations stand as representative of the global production.

\subsubsection{Indonesia}

The majority of Indonesian oil palm plantations by area are located in Sumatra, followed by Kalimantan. Kalimantan has experienced particularly rapid growth in oil palm plantations since the year 2000 (Gunarso et al., 2013; Austin et al., 2017). Estimates of the contribution of oil palm to deforestation are challenging and variable (Wicke et al., 2011). In Indonesia, the primary direct driver of deforestation has been logging (often illegal) rather than the expansion of oil palm plantations. However, oil palm plantations have frequently replaced previously forested land after logging and therefore are associated with the carbon loss from this land use change (Gunarso et al., 2013). Several studies have quantified the proportion of growth in oil palm area linked to deforestation (Tab. 5). Based on FAO data (2018), the expansion of oil palm in Indonesia was approximately $477 \mathrm{khay}^{-1}$ between 2007 and 2015.

The expansion of oil palm over forestlands in Indonesia has ranged from approximately 18 to $63 \%$ in recent years. We conservatively take a value of $30 \%$. Of this conversion, Austin et al. (2017) report that the majority (94.9\%) occurred in secondary forests and $5.1 \%$ in primary forests. In the body of the report, we give further details for Sumatra and Kalimantan.
Conversion of peatlands, often through the use of fire (although no longer legal), has contributed to considerable loss of carbon stocks (Gunarso et al., 2013). The estimated area of industrial oil palm plantations on peatlands in Indonesia increased from $19 \mathrm{kha}$ in 1990 to $1311 \mathrm{kha}$ in 2010 (Miettinen et al., 2012). Austin et al. (2017) estimate an expansion of $305 \mathrm{kha}$ on peatlands between 1995-2000 and 619 kha between 2010-2015 (20\% proportion for both periods). From Austin et al. (2017) and Gunarso et al. (2013), we estimate that for Sumatra, Kalimantan and Papua, the share of total expansion over native vegetation was approximately $50 \%$ and occurred in areas analogous to "tropical forest" and the other $50 \%$ in areas analogous to "wetland" (peatland). Carlson et al. (2013) projected that the land use change from the expansion of oil palm from 2010-2020 will conservatively result in emissions for which $56 \%$ are from the clearing of forests and $25 \%$ from the conversion of peatlands.

\subsubsection{Malaysia}

Forestlands in Malaysia have been relatively stable since 2010. On the other hand, oil palm has expanded significantly onto croplands and into the land use category "other" (see Appendix A). Some of these "other" land use classes may have originated on previously forested areas (Gunarso et al., 2013). A decline in permanent cropland has been observed since 1990 (Wicke et al., 2011). There is also evidence of an increase in clearing of land by $150 \%$ in Malaysia in the last decade (Geographical Magazine, 2018). The national harvested plantation area reached an estimated $4.86 \mathrm{Mha}$ in 2015 (FAO, 2018). Estimating this impact is challenging due to the often indirect relationship between deforestation and the establishment of new oil palm plantations (via prior logging). However, oil palm establishment has more directly driven deforestation in Malaysia than in Indonesia (Gunarso et al., 2013). This applies for the regions of Sabah and Sarawak (Gaveau et al., 2016), while deforestation in the Malaysia Peninsular has been more driven by the expansion of rubber and other crops (Gunarso et al., 2013).

Estimates of deforestation associated with palm oil production in Malaysia vary and are given in Table 6. In summary, the expansion of oil palm over forestlands in Malaysia has ranged from approximately 17 to $39 \%$ in recent years. We take a conservative estimate of $20 \%$ but note that it 
Table 6. Expansion over high carbon stock lands in Malaysia.

\begin{tabular}{lllll}
\hline Timeframe & Region & $\begin{array}{l}\text { Proportion of oil palm } \\
\text { area expansion associated } \\
\text { with deforestation (\%) }\end{array}$ & $\begin{array}{l}\text { Absolute expansion in } \\
\text { oil palm area associated } \\
\text { with deforestation (ha) }\end{array}$ & Study \\
\hline $1990-2005$ & Malaysia & $55-59$ & 1040000 to 1 109000 & Koh and Wilcove (2008) \\
$1990-2010$ & Malaysia & 17 & Not available & Geographical Magazine (2018) \\
$1990-2013$ & Malaysia & 38.9 & Not available & Vijay et al. (2016) \\
$1990-2010$ & Malaysia & 42 & 1365700 & Gunarso et al. (2013) \\
$1990-2010$ & Peninsular Malaysia & 25.1 & 281000 & Gunarso et al. (2013) \\
$1990-2010$ & Sabah & 59.6 & 689000 & Gunarso et al. (2013) \\
$1990-2010$ & Sarawak & 40.5 & 396500 & Gunarso et al. (2013) \\
\hline
\end{tabular}

Source: Prepared by the authors, using references cited within the table.

Table 7. Oilseed rape producing countries and risks associated with high carbon stock lands.

\begin{tabular}{lllll}
\hline Country & Forestland dynamics & $\begin{array}{l}\text { Total rapeseed } \\
\text { oil production } \\
\text { (Mt of oil) }\end{array}$ & $\begin{array}{l}\text { Share of global } \\
\text { production (\%) }\end{array}$ & $\begin{array}{l}\text { Approximate range } \\
\text { of OSR expansion } \\
\text { over native vegetation (\%) }\end{array}$ \\
\hline Canada & Net deforestation & 18.4 & 27 & 0 \\
China & Net afforestation/reforestation & 15.3 & 22 & Not applicable \\
Czech Republic & Net afforestation/reforestation & 1.4 & 2 & Not applicable \\
France & Net afforestation/reforestation & 4.7 & 7 & Not applicable \\
Germany & Net afforestation/reforestation & 4.6 & 7 & Not applicable \\
India & Net afforestation/reforestation & 6.8 & 10 & Not applicable \\
Poland & Net afforestation/reforestation & 2.2 & 3 & Not applicable \\
Romania & Net afforestation/reforestation & 1.3 & 2 & Not applicable \\
United Kingdom & Net afforestation/reforestation & 1.8 & 2 & Not applicable \\
United States & Net afforestation/reforestation & 1.4 & 10 & Not applicable \\
Other nations & - & 7.2 & 29 & - \\
EU28 & Net afforestation/reforestation & 19.7 & 100 & Not applicable \\
World & Net deforestation & 68.9 & & Not applicable \\
\hline
\end{tabular}

Source: Prepared by the authors.

Note: Total rapeseed oil production as in 2014 base-year (FAO, 2018). Risk associated with the likelihood that OSR may expand over native vegetation within the respective country, including forestlands and natural grasslands.

may be an underestimate due to the uncertainties related the definition of "other land", which are not considered as forestlands, but which may include peatlands and bare soils. On the other hand, the Malaysian government reports that the emissions associated with land use, land use change and forestry sector have roughly stabilised since 1995 (Ministry of Natural Resources and Environment Malaysia, 2015).

\subsection{Oilseed rape}

The production of rapeseed oil also has a concentrated market, with Canada, China and EU28 dominating the global production with about $78 \%$ of the global production. Including India and the United States, this total share increases to $90 \%$. It is third most important vegetable oil crop worldwide, behind oil palm and soybean with global production expanding by $40 \%$ between 2006 and 2016. All the assessed countries presented net afforestation/reforestation in the past decade, apart from Canada, which presented a small net deforestation area, based on data from FAO (2018). Thus, as shown in
Table 7, there is no apparent correlation between the recent expansion of oilseed rape and forest dynamics.

\section{Conclusion}

According to the analysis of the historical data and using the high ILUC-risk definition as it stands, we consider that the emissions associated with palm and soy oil production are likely to be significant, however we acknowledge that the actual emissions are both highly uncertain and spatially variable depending on the assessed country and sub-region. For oil palm we take Indonesia and Malaysia as proxy for the global position. We calculate an average expansion of $29 \%$ over high carbon stock land. For soy we calculate a global average of $19 \%$ expansion over high carbon stock land. We calculate the global average greenhouse gas emissions intensities based on the ILUC-risks as $56 \mathrm{gCO}_{2} \mathrm{eq} / \mathrm{MJ}$ for soy oil and $108 \mathrm{gCO}_{2} \mathrm{eq} / \mathrm{MJ}$ for palm oil. Future projections (OECD-FAO, 2017) suggest these numbers could drop significantly. We do not find evidence for high ILUC-risk 
expansion of oilseed rape, given that there is no apparent correlation between the recent expansion of oilseed rape and forest dynamics.

Conflicts of interest. This article is part of a research that was commissioned by Terres Univia (France) on behalf of the organisations of the French vegetable oil and protein sector to LCAworks Limited (United Kingdom). The funding source had no interference in the preparation of this document.

The authors have no competing interests to declare. The opinions and conclusions expressed in this study are those of the authors alone and do not necessarily reflect the views of their respective institutions of affiliation or the opinions of its funding source.

\section{References}

Austin KG, Mosnier A, Pirker J, McCallum I, Fritz S, Kasibhatla PS. 2017. "Shifting patterns of oil palm driven deforestation in Indonesia and implications for zero-deforestation commitments". Land Use Policy 69: 41-48. DOI: 10.1016/j.landuse pol.2017.08.036.

Barona E, Ramankutty N, Hyman G, Coomes OT. 2010. The role of pasture and soybean in deforestation of the Brazilian Amazon. Environ Res Lett 5: 024002.

Carlson KM, Curran LM, Asner GP, Pittman AM, Trigg SN, Adeney JM. 2013. "Carbon emissions from forest conversion by Kalimantan oil palm plantations". Nat Clim Change. Nature Publishing Group, Vol.3, pp. 283-287. DOI: 10.1038/ncli mate1702.

Edwards R, Padella M, Vorkapic V, Marelli L. 2014. Historical deforestation due to expansion of crop demand: Implications for biofuels. Joint Research Center (JRC) Science and Policy Reports, Ref. EUR 27118 EN. DOI: 10.2790/02220.

FAO. 2018. FAOSTAT-Online database of the UN Food and Agricultural Organization. Available from www.fao.org/faostat/en/.

Gaveau DLA, Sheil D, Husnayaen, et al. 2016. "Rapid conversions and avoided deforestation: Examining four decades of industrial plantation expansion in Borneo". Sci Rep. Nature Publishing Group, Vol. 6, 32017 p. DOI: 10.1038/srep32017.

Geographical Magazine. 2018. "Dossier palm oil", pp. 19-25.

Goni U. 2018. Soy destruction in Argentina leads straight to our dinner plates. Guard. Available from https://www.theguardian. com/environment/2018/oct/26/soy-destruction-deforestation-inargentina-leads-straight-to-our-dinner-plates.

Gunarso P, Hartoyo ME, Agus F, Killeen TJ. 2013. Oil palm and land use change in Indonesia, Malaysia and Papua New Guinea. In : Reports from the technical panels of the 2nd Greenhouse Gas Working Group of the Roundtable on Sustainable Palm Oil (RSPO). Available from https://www.researchgate.net/publica
tion/288658092_Oil_palm_and_land_use_change_in_Indone sia_Malaysia_and_Papua_New_Guinea.

Herrera LP, Panigatti JP, Barral MP, Blanco DE. 2013. Biofuels in Argentina: Impacts of soybean production on wetlands and water. Technical report by Wetlands International. ISBN 978-987-24710-8-8.

INRAD-CIRAD-AFZ. 2019. The INRA-CIRAD-AFZ feed tables. Online database. Available from https://feedtables.com/content/ tables.

Intergovernmental Panel on Climate Change (IPCC). 2000. Land use, land-use change and forestry. Geneva, Switzerland: IPCC Special Report, WMO and UNEP.

Koh LP, Wilcove DS. 2008. "Is oil palm agriculture really destroying tropical biodiversity?". Conserv Lett 1: 60-64. DOI: 10.1111/ j.1755-263X.2008.00011.x.

Larraquy M. 2016. Deforestación: en 7 años se perdió una superficie equivalente a la provincia de Jujuy. Clarín. Buenos Aires, Argentina.

Miettinen J, Hooijer A, Tollenaar D, et al. 2012. Historical analysis and projection of oil palm plantation extent on peatland in SE Asia; 2010 Situation. White Paper 17. Washington, D.C.: International Council on Clean Transportation (ICCT).

Ministry of Natural Resources and Environment Malaysia. 2015. Malaysia biennial update report to the UNFCCC. Putrajaya, Malaysia.

NEPCon. 2017. Soy risk assessment: Argentina. Technical Report, Version 1.2, NEPCon and Denmark's DANIDA, $127 \mathrm{p}$.

OECD-FAO. 2017. OECD-FAO Agricultural Outlook 20172026-Special Focus: Southeast Asia. Paris, France. DOI: 10.1787/agr_outlook-2017-en.

Overmars K, Edwards R, Padella M, Prins AG, Marelli L. 2015. Estimates of indirect land use change from biofuels based on historical data. JRC Science and Policy Report, Ref. no. EUR 26819 EN. DOI: 10.2790/3647.

RTRS. 2018. Round table on sustainable soy: About RTRS. Online Information Available from http://www.responsiblesoy.org/ about-rtrs/about-us/?lang=en.

Strapasson A. 2014. The limits of bioenergy: A complex systems approach to land use dynamics and constraints. Ph.D Thesis, Imperial College London, 233 p. Available from http://hdl.handle. net/10044/1/19269.

Valin H, Peters D, van den Berg M, et al. 2015. The land use change impact of biofuels consumed in the EU: Quantification of area and greenhouse gas impacts. Project no. BIENL1312. Ref. Ares (2015)417308. Technical Report, Ecofys, IIASA, E4Tech, 261 p.

Vijay V, Pimm SL, Jenkins CN, Smith SJ. 2016. The impacts of oil palm on recent deforestation and biodiversity loss. PLOS One. DOI: 10.1371/journal.pone.0159668.

Wicke B, Sikkema R, Dornburg V, Faaij A. 2011. "Exploring land use changes and the role of palm oil production in Indonesia and Malaysia". Land Use Policy. Elsevier Ltd, Vol. 28, pp. 193-206. DOI: 10.1016/j.landusepol.2010.06.001. 


\section{Appendix A Glossary of land use classifications.}

Source: FAO (2018).

Land use Description

Agricultural land

Agriculture

Arable land

Country area

Cropland

Forest land

Forestry

Forestry area actually irrigated Inland waters

Land area

Land under perm. meadows and pastures
Land used for cultivation of crops and animal husbandry. The total of areas under "Cropland" and "Permanent meadows and pastures".

The total of areas under "Land under temporary crops", "Land under temporary meadows and pastures", "Land with temporary fallow", "Land under permanent crops", "Land under permanent meadows and pastures", and "Land under protective cover". This category includes tilled and fallow land, and naturally grown permanent meadows and pastures used for grazing, animal feeding or agricultural purpose. Scattered land under farm buildings, yards and their annexes, and permanently uncultivated land, such as uncultivated patches, banks, footpaths, ditches, headlands and shoulders are traditionally included.

The total of areas under temporary crops, temporary meadows and pastures, and land with temporary fallow. Arable land does not include land that is potentially cultivable but is not normally cultivated.

Area under national sovereignty. It is the sum of land area, inland waters and coastal waters. It excludes the exclusive economic zone.

Land used for cultivation of crops. The total of areas under "Arable land" and "Permanent crops".

Land spanning more than 0.5 ha with trees higher than $5 \mathrm{~m}$ and a canopy cover of more than $10 \%$, or trees able to reach these thresholds in situ. Excludes land that is predominantly under agricultural or urban land use, and land that is predominantly used for maintenance and restoration of environmental function. Explanatory notes: (1) Forest land is determined both by the presence of trees and by the absence of other predominant land uses. The trees should be able to reach a minimum height of $5 \mathrm{~m}$ in situ. (2) Includes areas with young trees that have not yet reached but that are expected to reach a canopy cover of $10 \%$ and tree height of $5 \mathrm{~m}$. It also includes areas that are temporarily unstocked owing to clear-cutting as part of a forest management practice or natural disasters, and that are expected to be regenerated within five years. Local conditions may, in exceptional cases, justify the use of a longer time frame. (3) Includes forest roads, firebreaks and other small open areas. (4) May include forest land in national parks, nature reserves and other protected areas, such as those of specific environmental, scientific, historical, cultural or spiritual interest. (5) Includes windbreaks, shelter belts and corridors of trees with an area of more than 0.5 ha and width of more than $20 \mathrm{~m}$. (6) Includes abandoned shifting cultivation land with a regeneration of trees that have, or is expected to reach, a canopy cover of $10 \%$ and tree height of $5 \mathrm{~m}$. (7) Includes areas with mangroves in tidal zones, regardless of whether this area is classified as land area or not. (8) Includes areas with bamboo and palms provided that land use, height and canopy cover criteria are met. (9) Some agroforestry systems such as the taungya system, where crops are grown only during the first years of the forest rotation should be classified as forest. (10) Excludes: tree stands in agricultural production systems, such as fruit-tree plantations ( $\rightarrow$ Permanent crops), oil palm plantations, rubber and Christmas trees $(\rightarrow$ Permanent crops) and agroforestry systems when crops are grown under tree cover

Land used for forestry. Excludes land that is predominantly under agricultural or urban use.

Land area actually irrigated that is land used for Forestry.

Inland waters are areas corresponding to natural or artificial water courses, serving to drain natural or artificial bodies of water, including lakes, reservoirs, rivers, brooks, streams, ponds, inland canals, dams, and other land-locked waters. The banks constitute limits whether the water is present or not. Country area excluding area under inland waters and coastal waters. Land used permanently (five years or more) to grow herbaceous forage crops through cultivation or naturally (wild prairie or grazing land). Permanent 
Appendix A (continued).

Land use

Land under permanent crops

Land under protective cover

Land under temp. meadows and pastures

Land under temporary crops

Land with temporary fallow

Other land

Other naturally regenerated forest

Perm. meadows \& pastures - Cultivated Perm. meadows \& pastures - Nat. growing Perm. meadows \& pastures area actually irrig. Perm. meadows \& pastures area certified organic Perm. meadows \& pastures area under organic agric.

Planted forest
Description

meadows and pastures on which trees and shrubs are grown should be recorded under this heading only if the growing of forage crops is the most important use of the area. Measures may be taken to keep or increase productivity of the land (i.e., use of fertilizers, mowing or systematic grazing by domestic animals.) This class includes: (1) Grazing in wooded areas (agroforestry areas, for example).

(2) Grazing in shrubby zones (heath, maquis, garigue). (3) Grassland in the plain or low mountain areas used for grazing: land crossed during transhumance where the animals spend a part of the year (approximately 100 days) without returning to the holding in the evening: mountain and subalpine meadows and similar; and steppes and dry meadows used for pasture.

Land cultivated with long-term crops which do not have to be replanted for several years (such as cocoa and coffee), land under trees and shrubs producing flowers (such as roses and jasmine), and nurseries (except those for forest trees, which should be classified under "Forestry"). Permanent meadows and pastures are excluded from land under permanent crops.

Land used for agriculture occupied by dwellings on farms, etc.: dwellings, operating buildings (hangars, barns, cellars, greenhouses, silos), buildings for animal production (stables, cowsheds, pig sheds, sheep pens, poultry yards), family gardens, farmyards.

Land temporarily cultivated with herbaceous forage crops for mowing or pasture. A period of less than five years is used to differentiate between temporary and permanent meadows and pastures.

Land used for crops with a less-than-one-year growing cycle, which must be newly sown or planted for further production after the harvest. Some crops that remain in the field for more than one year may also be considered as temporary crops e.g., asparagus, strawberries, pineapples, bananas and sugar cane.

Multiple-cropped areas are counted only once.

Land that is not seeded for one or more growing seasons. The maximum idle period is usually less than five years. This land may be in the form sown for the exclusive production of green manure. Land remaining fallow for too long may acquire characteristics requiring it to be reclassified, as for instance "Permanent meadows and pastures" if used for grazing or haying.

Land area not classified as "Agriculture" and "Forestry". It includes SEEA categories "Land used for aquaculture", "Built-up and related areas", "Land Use for maintenance and restoration of environmental functions", "Other uses of land not elsewhere classified", and "Land not in use".

Naturally regenerated forest where there are clearly visible indications of human activities. Explanatory notes: 1. Includes selectively logged-over areas, areas regenerating following agricultural land use, areas recovering from humaninduced fires, etc.2. Includes forests where it is not possible to distinguish whether planted or naturally regenerated.3. Includes forests with a mix of naturally regenerated trees and planted/seeded trees, and where the naturally regenerated trees are expected to constitute more than $50 \%$ of the growing stock at stand maturity.

Land under "Permanent meadows and pastures" that is managed and cultivated. Land under "Permanent meadows and pastures" that is naturally growing. Agricultural land actually irrigated that is Permanent meadows and pastures. Permanent meadows and pastures area certified organic.

Permanent meadows and pastures area certified organic and/or in-conversion to organic.

Forest predominantly composed of trees established through planting and/or deliberate seeding. Explanatory notes: (1) In this context, predominantly means that the planted/seeded trees are expected to constitute more than $50 \%$ of the growing stock at maturity. (2) Includes coppice from trees that were originally planted or seeded. (3) Includes rubberwood, cork oak and Christmas tree plantations. (4) Excludes self-sown trees of introduced species. 
Appendix A (continued).

Land use

Primary forest

\section{Description}

Naturally regenerated forest of native species, where there are no clearly visible indications of human activities and the ecological processes are not significantly disturbed. Explanatory note: (1) Some key characteristics of primary forests are: (a) they show natural forest dynamics, such as natural tree species composition, occurrence of dead wood, natural age structure and natural regeneration processes; (b) the area is large enough to maintain its natural characteristics; (c) there has been no known significant human intervention or the last significant human intervention was long enough ago to have allowed the natural species composition and processes to have become re-established.

Cite this article as: Strapasson A, Falcão J, Rossberg T, Buss G, Woods J, Peterson S. 2019. Land Use Change and the European Biofuels Policy: The expansion of oilseed feedstocks on lands with high carbon stocks. OCL 26: 39. 